\title{
ОРГАНІЗАЦІЯ ДЕРЖАВНОГО НАГЛЯДУ У ЛІСОВОМУ ГОСПОДАРСТВІ З УРАХУВАННЯМ ЙМОВІРНОСТІ ВИНИКНЕННЯ НЕПЕРЕДБАЧУВАНИХ ПОДІЙ І ОЧІКУВАНОЇ ТЯЖКОСТІ ШКОДИ
}

\section{М. О. Радіонов}

Департамент нагляду в промисловості і на об’єктах підвищеної небезпеки Державної служби України з питань праці (відділ нагляду в агропромисловому комплексі та соціально-культурній сфері)

вул. Десятинна 14, м. Київ, 01601, Україна. E-mail: dspmykolaradionov@ gmail.com

Висвітлено питання організації, планування та здійснення заходів державного нагляду за додержанням законодавства у сфері охорони праці в частині безпечного ведення робіт на підприємствах лісового господарства України. Проаналізовано рівень виробничого травматизму та частоту його настання. Визначено основні види подій, що призвели до нещасних випадків зі смертельними наслідками та причини їх виникнення у галузі лісового господарства. Дано визначення поняттям ризик та професійний ризик. Визначено, що: управління ризиком містить збір та аналіз інформації про виробничу безпеку на кожному робочому місці, аналіз ризику та контроль промислової безпеки; аналіз ризику є ключовою ланкою у забезпеченні безпеки, що базується на зібраній інформації та визначає заходи щодо контролю безпеки промислових об'єктів. Розглянуто принципи ризикорієнтованого підходу до планування, організації та здійснення заходів державного нагляду на підприємствах лісової галузі та модель оцінки ризиків на основі комбінації ймовірності виникнення та очікуваної тяжкості шкоди від непередбачуваних подій. Запропоновано здійснення організації та планування наглядової діяльності територіальними органами Держпраці на основі оцінки виробничих ризиків з урахуванням ймовірності виникнення непередбачуваних подій (аварій, нещасних випадків, інцидентів та ін.) і очікуваної тяжкості від їх шкоди. Надано пропозиції щодо шляхів підвищення ефективності здійснення заходів державного нагляду на підприємствах лісового господарства, в тому числі - на основі застосування принципів ризик-орієнтованого підходу. Автором запропоновано при збігу у суб'єктів господарювання факторів надвисокої ймовірності виникнення непередбачуваної події та нестерпної характеристики тяжкості шкоди, віднести їх до суб'єктів господарювання 3 надвисоким ступенем ризику для безпеки життя і здоров'я людей та визначити періодичність проведення планових перевірок їх не рідше одного разу на рік.

Ключові слова: державний нагляд, лісове господарство, ризик, оцінка ризиків, ймовірність небезпечної події, очікувана тяжкість шкоди.

\section{ОРГАНИЗАЦИЯ ГОСУДАРСТВЕННОГО НАДЗОРА В ЛЕСНОМ ХОЗЯЙСТВЕ С УЧЕТОМ ВЕРОЯТНОСТИ ВОЗНИКНОВЕНИЯ НЕПРЕДСКАЗУЕМЫХ СОБЫТИЙ И ОЖИДАЕМОЙ ТЯЖЕСТИ ВРЕДА}

\section{Н. А. Радионов}

Департамент надзора в промышленности и на объектах повышенной опасности Государственной службы

Украины по вопросам труда (отдел надзора в агропромышленном комплексе и социально-культурной сфере) ул. Десятинная 14, г. Киев, 01601, Украина. E-mail: dspmykolaradionov@ gmail.com

Представлены вопросы организации, планирования и осуществления мероприятий государственного надзора за соблюдением законодательства в сфере охраны труда в части безопасного ведения работ на предприятиях лесного хозяйства Украины. Проанализирован уровень производственного травматизма и его частота. Определены основные виды событий, которые привели к несчастным случаям со смертельным исходом и причины их возникновения в отрасли лесного хозяйства. Дано определение понятию риска и профессионального риска. Определено, что: управление риском содержит сбор и анализ информации о производственной безопасности на каждом рабочем месте, анализ риска и контроль за промышленной безопасностью; анализ риска является ключевым звеном в обеспечении безопасности, основанной на собранной информации и определяет меры по контролю за безопасностью промышленных объектов. Рассмотрены принципы риск-ориентированного подхода к планированию, организации и осуществлению мероприятий государственного надзора на предприятиях лесной отрасли и модель оценки рисков на основе комбинации вероятности возникновения и ожидаемой тяжести вреда от непредсказуемых событий. Предложено осуществление организации и планирования надзорной деятельности территориальными органами Гоструда на основе оценки производственных рисков с учетом вероятности возникновения непредсказуемых событий (аварий, несчастных случаев, инцидентов и др.) и ожидаемой тяжести от их вреда. Даны предложения относительно путей повышения эффективности осуществления мероприятий государственного надзора на предприятиях лесного хозяйства, в том числе - на основе применения принципов риск-ориентированного подхода. Автором предложено при совпадении у субъектов хозяйствования факторов сверхвысокой вероятности возникновения непредвиденного события и невыносимой характеристики тяжести вреда, отнести их к субъектам хозяйствования со сверхвысокой степенью риска для безопасности жизни и здоровья людей и определить периодичность проведения плановых проверок их не реже одного раза в год.

Ключевые слова: государственный надзор, лесное хозяйство, риск, оценка рисков, вероятность наступления определенного опасного события, ожидаемая тяжесть вреда. 
АКТУАЛЬНІСТЬ РОБОТИ. Протягом останніх років кількість травмованих і загиблих від виробничих травм працівників лісової галузі України на 1 млн м ${ }^{3}$ заготівлі деревини поступово збільшується.

Ситуацію з рівнем виробничого травматизму, що склалася навколо лісогосподарських підприємств неможливо виправити без впровадження функціонування ефективної системи державного нагляду за станом охорони праці на основі оцінки ризику виробничого травматизму у травмонебезпечних галузях економіки $з$ елементами управління та мінімізації виробничих ризиків [1].

Ризик $є$ постійним супутнім фактором виробничої діяльності, він фактично і $є$ мірою небезпеки. Для управління ризиком його необхідно проаналізувати та оцінити. Ризик - це ступінь ймовірності певної негативної події, яка може відбутися в певний час або за певних обставин на території об'єкта підвищеної небезпеки або за його межами [2, 3]. Професійний ризик - це поєднання ймовірності настання нещасного випадку, пошкодження (втрати) здоров'я або загибелі працівника внаслідок впливу на нього небезпечного чи шкідливого виробничого чинника при виконанні ним своїх трудових обов'язків $з$ тяжкістю наслідків (травми чи шкоди для здоров'я).

МАТЕРІАЛ І РЕЗУЛЬТАТИ ДОСЛІДЖЕНЬ. Аналізуючи рівень виробничого травматизму із смертельними наслідками в державі за останні роки, з'ясовано, що серед усіх галузей економіки України, у лісовому господарстві реєструється одна 3 найбільших кількостей загиблих на 100 тисяч працюючих, яка за коефіцієнтом частоти смертельного травматизму $-K_{\text {чс }}=$ (кількість потерпілих/середньооблікова кількість працюючих) х $10^{5}-\epsilon$ найбільш травмонебезпечною у 2017 році та максимально наближеною до «лідера 2018 року в Україні» за рівнем загиблих на виробництві - вугільної галузі [4]. Коефіцієнт летального травматизму у лісовому господарстві у 2018 році у 6,5 разів більший, ніж у середньому по країні.
Згідно зі звітними даними Держпраці за формою 3-НД 2018 року територіальні органи Служби здійснювали державний нагляд за 2228 суб'єктами господарювання лісової галузі проти 2295 у 2017 році.

Кількість працюючих на лісогосподарських підприємствах у 2018 році складала - 69406 проти 67 070, що на 2336 осіб більше, ніж у 2017 році. Це вказує на позитивні зміни у ставленні роботодавців щодо офіційного працевлаштування працюючих у лісовій галузі.

Протягом 2015-2017 років серед усіх галузей економіки України в середньому на один нещасний випадок зі смертельним наслідком офіційно реєструвалось по 11 випадків загального травматизму на виробництві. Разом $з$ цим, у 2018 році цей показник зменшився до 10 травмованих на виробництвах на один летальний випадок серед усіх галузей економіки країни. Співвідношення кількості смертельних випадків на виробництві до кількості загально травмованих працівників України у 2018 році складає на одного загиблого: у вугільній промисловості зареєстровано - 35 травмованих, у машинобудуванні - 19, у соціально-культурній сфері - 16, в агропромисловому комплексі - 8 таких випадків, у сільському господарстві - 7 випадків, а в лісовому господарстві - лише 4 випадки загального травмування працівників, що вказує на суттєві масштаби приховування нещасних випадків на виробництві в галузі лісового господарства.

За результатами аналізу з'ясовано, що за кількістю смертельно травмованих осіб на 100 тис. працюючих на лісогосподарських підприємствах України, лісова галузь у 2017 році знаходилась на першому місці, а у 2018 році - на другому місці серед усіх галузей економіки України. Максимальний середній коефіцієнт частоти нещасних випадків із смертельними наслідками $\left(K_{4 c}\right)$ за 2015-2018 роки зареєстровано у суб'єктів господарювання лісової галузі (табл. 1).

Таблиця 1 - Динаміка коефіцієнту частоти смертельного травматизму в Україні за галузями нагляду (на $10^{5}$ працюючих)

\begin{tabular}{|l|c|c|c|c|c|}
\hline \multicolumn{1}{|c|}{ Галузі нагляду } & 2015 & 2016 & 2017 & 2018 & $\begin{array}{c}\text { Середній } K_{\text {чс }} \\
\text { за 2015-2018 роки }\end{array}$ \\
\hline Лісове господарство & 17 & 25 & 28 & 19 & 22,2 \\
\hline Вугільна промисловість & 17 & 21 & 25 & 24 & 21,7 \\
\hline Автомобільний транспорт & 9 & 15 & 13 & 14 & 12,7 \\
\hline Гірничорудна та нерудна промисловість & 10 & 15 & 6 & 14 & 11,2 \\
\hline Будівництво & 9 & 11 & 14 & 11 & 11,2 \\
\hline Котлонагляд та підйомні споруди & 1 & 8 & 13 & 8 & 7,5 \\
\hline Металургійна промисловість & 6 & 6 & 6 & 10 & 7 \\
\hline Енергетика & 6 & 5 & 6 & 4 & 5,2 \\
\hline Деревообробна промисловість & 4 & 2 & 7 & 5 & 4,5 \\
\hline Сільське господарство & 5 & 4 & 4 & 3 & 4 \\
\hline Залізничний транспорт, метрополітен & 5 & 4 & 3 & 3 & 3,7 \\
\hline Хімічна промисловість & 6 & 3 & 1 & 5 & 3,7 \\
\hline $\begin{array}{l}\text { ЖКГ-3 (здавання в оренду власного } \\
\text { нерухомого житла, ландшафти) }\end{array}$ & 2 & 4 & 3 & 4 & 3,2 \\
\hline
\end{tabular}


Рівень загального травматизму у суб'єктів господарювання лісової галузі за кількістю травмованих працівників (коефіцієнт частоти загального травматизму $-K_{\text {чз }}$ ) протягом 2017-2018 років знаходиться на п'ятому місці серед усіх галузей економіки України (табл. 2). У 2018 році в лісовій галузі загинуло 13 працівників, що на 32 \% менше порівняно 3 аналогічним періодом минулого року (у 2017 році-19).

Разом 3 цим, у 2015-2017 рр. загальна кількість нещасних випадків на 1 млн м ${ }^{3}$ заготівлі деревини на лісогосподарських підприємствах щорічно збільшується. У 2017 році рівень травмованих працівників порівняно з 2015 роком збільшився на $67 \%$ та є найбільшим за останні п'ять років в Україні (рис. 1,a).

Кількість загиблих працівників лісогосподарських підприємств на 1 млн м ${ }^{3}$ заготівлі деревини, починаючи з 2013 року, поступово збільшується. У 2017 році рівень смертельних випадків на виробництвах лісової галузі порівняно з 2015 роком збільшився майже у 2,5 рази і $є$ також найбільшим за останні п’ять років в Україні (рис. 1,б) [5].

Таблиця 2 - Динаміка коефіцієнту частоти загального травматизму в Україні за галузями нагляду на $10^{5}$ працюючих

\begin{tabular}{|l|c|c|c|}
\hline \multicolumn{1}{|c|}{ Галузі нагляду } & 2018 & 2017 & $(+/-)$ \\
\hline Вугільна промисловість & $K_{\text {}_{3}}$ & $K_{\text {чз }}$ & -12 \\
\hline Целюлозно-паперова промисловість & 841 & 853 & -59 \\
\hline Металургійна промисловість & 146 & 205 & -6 \\
\hline Гірничорудна та нерудна промисловість & 121 & 127 & -27 \\
\hline Лісове господарство & 112 & 139 & -38 \\
\hline ЖКГ-2 (водо-каналізаційне господарство) & 68 & 106 & -28 \\
\hline Машинобудування & 62 & 90 & 7 \\
\hline Деревообробна промисловість & 62 & 61 & -14 \\
\hline Автомобільний транспорт & 61 & 75 & -13 \\
\hline Пошта, зв'язок & 53 & 66 & 10 \\
\hline Будівництво & 44 & 34 & -15 \\
\hline Водний транспорт & 43 & 58 & -17 \\
\hline Харчова та переробна промисловість & 42 & 59 & -5 \\
\hline Енергетика & 39 & 44 & -4 \\
\hline Хімічна промисловість & 38 & 42 & -6 \\
\hline Нафтогазовидобувна промисловість та геологорозвідка & 31 & 36 & -5 \\
\hline Сільське господарство & 21 & 22 & -1 \\
\hline Соціально-культурна сфера та торгівля & 17 & 20 & -3 \\
\hline Газова промисловість & 17 & 19 & -2 \\
\hline
\end{tabular}

У результаті детального аналізу статистичних даних про нещасні випадки зі смертельними наслідками на виробництві з'ясовано, що протягом останніх років найбільша кількість працівників лісового господарства гине під час падіння дерева (або гілки) на потерпілого. На цю подію щороку припадає майже 70 \% смертельно травмованих у лісовій галузі.

Видами подій, що призвели до настання нещасних випадків зі смертельними наслідками у 2018 році $\epsilon$ :

- падіння, обрушення, обвалення предметів (дерев, гілок) - загинуло 9 осіб (або 68 \%);

- дорожньо-транспортні пригоди - 1 особа (або $8 \%)$

- ушкодження внаслідок контакту з комахами 1 особа (або $8 \%$ );

- пожежа - 1 особа (або 8 \%);

- падіння потерпілого, під час пересування 1 особа (або $8 \%$ ) (рис. 2).
Згідно $з$ аналізом наглядової діяльності Держпраці, проведеним за останні роки, частка щорічних перевірок суб'єктів господарювання лісової галузі та їх виробничих об'єктів у 2014-2015 роках зменшилась. Це зумовлено тим, що статтею 31 Закону України «Про державний бюджет України на 2014 рік» (зі змінами внесеними ЗУ від 31.07.2014 № 1622-VII), Постановою КМУ від 13.08.2014 № 408 «Питання запровадження обмежень на проведення перевірок державними інспекціями та іншими контролюючими органами», пункту 8 розділу III Прикінцевих положень Закону України «Про внесення змін та визнання такими, що втратили чинність деяких законодавчих актів України» від 28.12.2014 № 76-VIII з серпня 2014 року було запроваджено мораторій на проведення перевірок суб'єктів господарювання [6]. 


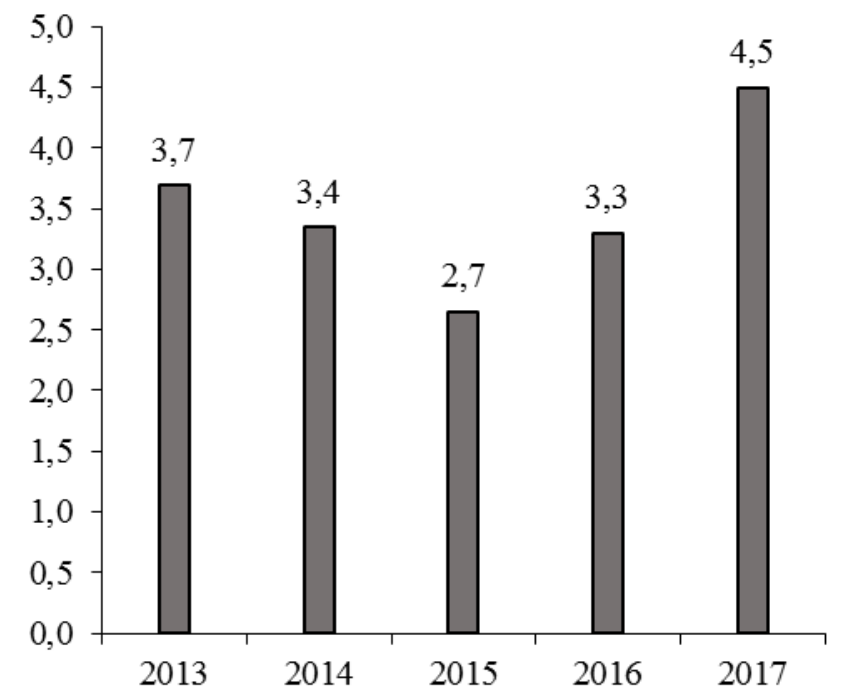

a)

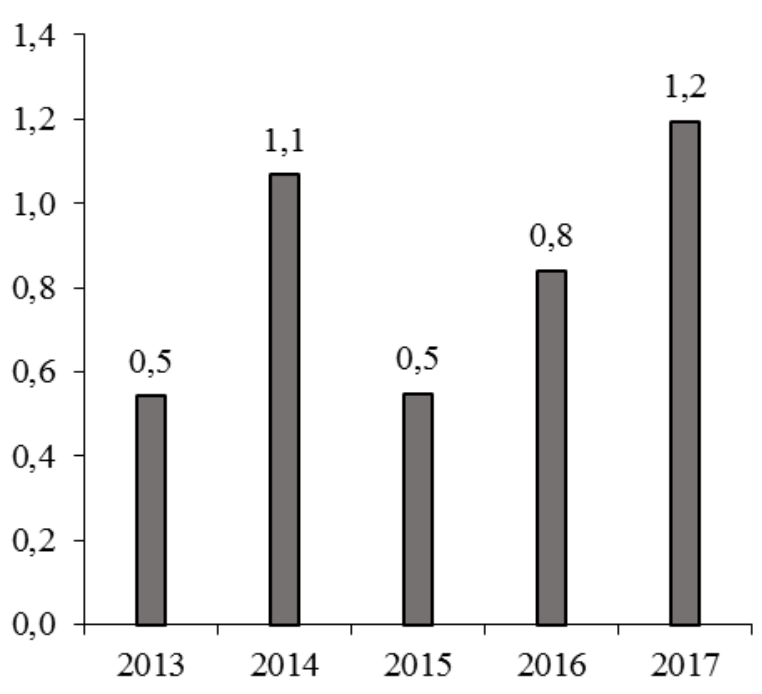

б)

Рисунок 1 - Динаміка кількості травмованих (а), загиблих (б) на 1 млн м³ заготівлі деревини лісогосподарськими підприємствами України (за 2018 рік інформація про обсяги заготівлі деревини підприємствами лісової галузі станом на 01.03.2019 року у Держкомстаті України - відсутня)

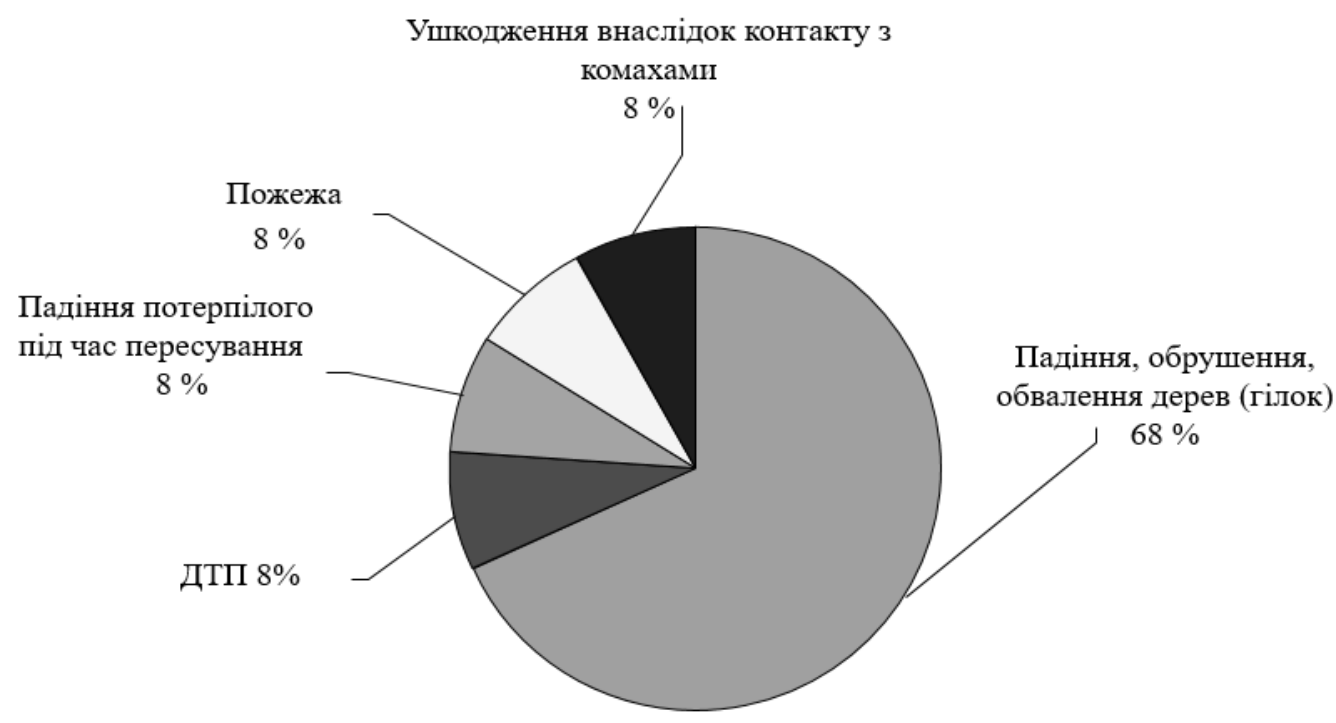

Рисунок 2 - Розподіл за видами подій нещасних випадків зі смертельними наслідками у лісовій галузі за 2018 рік

Як показує дослідження, збільшення коефіцієнту тяжкості потерпілих від нещасних випадків у лісовому господарстві відбувається при зменшенні кількості перевірених у галузі суб'єктів господарювання, а його зменшення реєструється під час активізації перевірок посадових осіб Держпраці (табл. 3).

Зміни коефіцієнту тяжкості потерпілих від нещасних випадків піднаглядових підприємств, в залежності від інспекційної діяльності посадових осіб суб'єктів інспекційної діяльності Держпраці в $t$-му році порівняно з попереднім роком визначаємо за виразом:

$$
\pm \Delta K_{T t}=\sum_{i=1}^{n} f K_{i j} \sqrt{\left(\phi_{o j}+\phi_{c j}\right)^{2}}
$$

де $n$ - фактична чисельність державних інспекторів $i$-того суб'єкта інспекційної діяльності; $f$ - функція залежності зміни кількості потерпілих від нещасних випадків на виробництві при зміні кількості заходів державного нагляду $i$-тим суб'єктом інспекційної діяльності Держпраці; $K_{i j}$ - кількість перевірок $i$-того суб'єкта інспекційної діяльності $j$-ої галузі економіки; $\phi o j$ - частка перевірених об'єктів господарювання $j$-ої галузі економіки; $\phi c j$ - частка перевірених суб'єктів господарювання $j$-ої галузі економіки. 
Таблиця 3 - Динаміка зміни показників характеристики рівня виробничого травматизму залежно від частки перевірених об’єктів і суб’єктів господарювання лісової галузі

\begin{tabular}{|c|c|c|c|c|c|c|}
\hline Рік & $\begin{array}{c}\text { Частка охоплення } \\
\text { державним нагля- } \\
\text { дом суб'єктів, } \%\end{array}$ & $\begin{array}{c}\text { Частка охоп- } \\
\text { лення держав- } \\
\text { ним наглядом } \\
\text { об’єків, \% }\end{array}$ & $\kappa_{T}$ & $\begin{array}{c}\text { Загальний } \\
\text { травматизм }\end{array}$ & $\begin{array}{c}\text { Смертельний } \\
\text { травматизм }\end{array}$ & $\begin{array}{c}\text { Заготівля } \\
\text { деревини } \\
\text { тис. м }\end{array}$ \\
\hline 2013 & 8,60 & 10,06 & 19,68 & 75 & 11 & 20340,6 \\
\hline 2014 & 4,01 & 7,95 & 27,17 & 69 & 22 & 20672,4 \\
\hline 2015 & 1,51 & 0,99 & 42,13 & 58 & 12 & 21924,2 \\
\hline 2016 & 9,59 & 7,13 & 35,84 & 74 & 17 & 22612,8 \\
\hline 2017 & 17,82 & 7,85 & 24,63 & 71 & 19 & 21923,0 \\
\hline 2018 & 15,71 & 5,15 & 37,26 & 47 & 13 & $-*$ \\
\hline
\end{tabular}

*Примітка: за 2018 рік інформація про обсяги заготівлі деревини підприємствами лісової галузі України станом на 01.03.2019 р. у Держкомстаті України - відсутня)

Результат дослідження залежності зміни кількісної характеристики рівня виробничого травматизму від щільності заходів державного нагляду у сфері охорони праці, з великою ймовірністю показує, що введення в Україні мораторію на перевірки суттєво вплинуло на зменшення частки охоплених державним наглядом підприємств лісового господарства, у зв'язку з чим, збільшився коефіцієнт тяжкості нещасних випадків потерпілих галузі $\left(K_{T}\right)$. У період дії обмежень на проведення перевірок з питань охорони праці та промислової безпеки, у 2015 році, зафіксовано найменший відсоток охоплення інспекційною діяльністю суб'єктів лісової галузі, при цьому зареєстровано максимальне за останні п'ять років значення коефіцієнту тяжкості - 42,13 [4]. Ці дані підтверджують інформацію щодо значних масштабів приховування нещасних випадків на виробництві в галузі лісового господарства України, особливо в періоди законодавчого обмеження на проведення перевірок державними інспекціями та іншими контролюючими органами.

Після завершення мораторію, починаючи з 2015 року, кількість перевірок підприємств лісової галузі, проведених суб'єктами інспекційної діяльності територіальних органів Держпраці, поступово збільшується. У 2017 році частка перевірених господарюючих суб'єктів лісового господарства порівняно 3 2015 роком збільшилась майже у 12 разів, та досягла максимального значення за останні п'ять років до 17,8\% перевірених лісогосподарських підприємств від загальної кількості піднаглядових суб'єктів господарювання лісової галузі, при цьому на 41,5 \% зменшився і коефіцієнт тяжкості потерпілих від нещасних випадків у лісовому господарстві України (табл. 3, рис. 3).

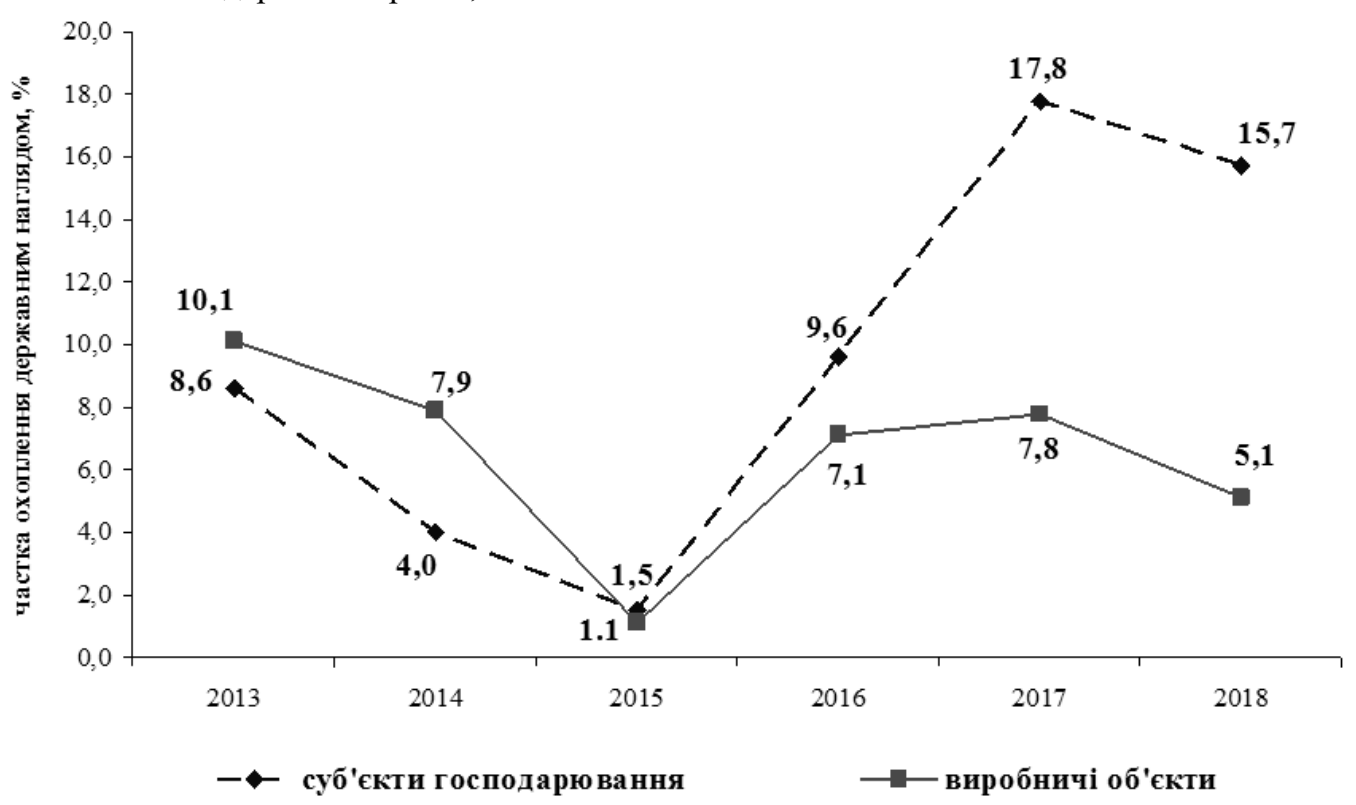

Рисунок 3 - Динаміка частки суб'єктів господарювання та виробничих об'єктів лісового господарства, які охоплені державним наглядом 
Така сама ситуація склалася 3 динамікою частки охоплення державним наглядом виробничих об'єктів лісогосподарських підприємств. Як видно 3 рис. 3, поступове збільшення частки охоплених державним наглядом виробничих об'єктів, після закінчення обмежень на здійснення перевірок, спостерігається, як і збільшення частки охоплення перевірками підприємств лісового господарства, у період 2015-2017 років.

У 2018 році, аналогічно зменшенню на 2,1 \% частки перевірених суб'єктів господарювання, на 2,7 \% зменшена кількість охоплених перевірками виробничих об'єктів лісового господарства. Усього в 2018 році перевірено 5,1 \% об'єктів лісової галузі від загальної кількості офіційно зареєстрованих в державі, що майже у два рази менше, ніж у 2013 році до запровадження мораторію на здійснення заходів державного нагляду [8].

У зв'язку з високим рівнем виробничого травматизму у суб'єктів господарювання лісової галузі та недостатньою ефективністю інспекційної діяльності за додержанням законодавства у сфері охорони праці територіальних органів Держпраці, ситуацію на підприємствах лісового господарства неможливо кардинально виправити без впровадження функціонування в Україні сучасної європейської системи управління охороною праці з елементами оцінки, управління та мінімізації виробничих ризиків.

У світі існує багато визначень терміну ризик. Серед багатьох визначень цієї характеристики небезпеки, найбільш уживаною в СС, є формула поєднання ймовірності та наслідків настання певної небезпечної події. За визначенням ризик є добутком ймовірності настання певної події та ступеню їі тяжкості (наслідки, викликані такою подією) [9]:

$$
R=P \times E,
$$

де $P$ - ймовірність настання певної небезпечної події; $E$ - ступінь тяжкості події (наслідки, викликані такою подією).

Прийнятний ризик - це ризик, який був зменшений до рівня, який може бути прийнятий суб'єктом господарювання, 3 врахуванням його юридичних обов'язків та власних правил [10].

Аналіз та оцінка виробничих ризиків є частиною системного підходу до прийняття організаційних, методичних та технічних рішень, процедур і практичних заходів у вирішенні питань попередження та зменшення рівня небезпеки виробничих аварій для життя людини, захворювань або травм, збитків майна та навколишнього середовища, що називається у нашій країні - забезпеченням виробничої безпеки, а за кордоном - управління ризиком.

Управління ризиком містить збір та аналіз інформації про виробничу безпеку на кожному робочому місці, аналіз ризику та контроль промислової безпеки. Аналіз ризику є ключовою ланкою у забезпеченні безпеки, що базується на зібраній інформації та визначає заходи щодо контролю безпеки промисло- вих об'єктів. Процедура аналізу ризику є складовою частиною декларування безпеки виробничих об'єктів, експертизи промислової безпеки, економічного аналізу безпеки та інших видів аналізу і оцінки стану безпеки виробничих об'єктів та територій на яких можливі техногенні аварії та надзвичайні ситуації [11].

Основними заходами для забезпечення якості проведення аналізу ризиків у лісовому господарстві $\epsilon$ планування та організація робіт, ідентифікація небезпек, оцінка ризику та розробка рекомендацій щодо зменшення негативного впливу та мінімізації виробничих ризиків (управління ризиками).

До теперішнього часу, жодним з територіальних органів Держпраці, при формуванні планів здійснення заходів державного нагляду (контролю) на наступний плановий період, не враховувались результати оцінки виробничих ризиків, проведених наглядовими органами у сфері охорони праці та вжиті господарюючими суб'єктами лісової галузі заходи щодо управління та оцінки ризиків виникнення нещасних випадків на виробництві, а також усунення і мінімізації шкідливих та небезпечних факторів на робочих місцях.

3 метою спрощення методики планування інспекційної діяльності при здійсненні процесу оцінки ризиків, для визначення вираження ступеню ризику, ймовірності його матеріалізації та тяжкості наслідків, замість використання недостовірних на даний час абсолютних показників виробничого травматизму, була створена шкала з чотирма рівнями.

В рамках методики планування інспекційної діяльності на основі ймовірності виникнення непередбачуваної події (нещасний випадок, інцидент, аварія та ін.), ступінь ймовірності події (NP) $є$ функцією вагомості недоліку та частоти або ймовірності його прояву, яка розраховується за формулою [10]:

$$
N R=N P \times N C,
$$

де $N P$ - ступінь ймовірності наслідків; $N C$ - рівень вагомості наслідків.

Вагомість недоліку $(N D)$ складається із сукупності очікуваної матеріалізації комплексу чинників ризику, що піддавалися зваженню, та їхнього прямого причинно-наслідкового зв'язку 3 ймовірною надзвичайною подією. Відповідність між вагомістю недоліку та числовими значеннями наведено в табл. 4.

Планування територіальними органами Держпраці наглядової діяльності суб'єктів господарювання лісової галузі необхідно здійснювати з використанням розрахунків, проведених на основі оцінки виробничих ризиків 3 урахуванням ймовірності виникнення непередбачуваних подій (аварій, нещасних випадків, інцидентів та ін.) і очікуваної тяжкості шкоди. Оцінка ризиків на основі комбінації ймовірності виникнення та очікуваної тяжкості шкоди від непередбачуваних подій показано у табл. 5. 
Таблиця 4 - Вагомість недоліку залежно від ступеня ймовірності виникнення непередбачуваної події

\begin{tabular}{|l|c|l|}
\hline \multicolumn{1}{|c|}{ Вагомість недоліку } & $N D$ & \multicolumn{1}{|c|}{ Тлумачення } \\
\hline Дуже вагомий недолік (MD) & 10 & $\begin{array}{l}\text { Наявність істотних чинників ризику. Комплекс стандартних } \\
\text { запобіжних заходів не } \epsilon \text { ефективним }\end{array}$ \\
\hline Вагомий (D) & 6 & $\begin{array}{l}\text { Наявність деяких чинників ризику, які необхідно усунути. } \\
\text { Наявні запобіжні заходи не дуже ефективні }\end{array}$ \\
\hline Задовільний (M) & 2 & $\begin{array}{l}\text { Чинники ризику невеликої ваги. Запобіжні заходи щодо ри- } \\
\text { зику мають певну ефективність }\end{array}$ \\
\hline Прийнятний (А) & - & $\begin{array}{l}\text { Відхилень від норм не виявлено. Ризики виникнення непе- } \\
\text { редбачуваних подій знаходяться під контролем }\end{array}$ \\
\hline
\end{tabular}

Таблиця 5 - Оцінка ризиків залежно від ймовірності виникнення та очікуваної тяжкості шкоди

\begin{tabular}{|c|c|c|c|c|}
\hline \multirow{2}{*}{\multicolumn{2}{|c|}{ Величина ризику }} & \multicolumn{3}{|c|}{ Тяжкість очікуваної шкоди } \\
\hline & & Дещо шкідливий & Шкідливий & Вкрай шкідливий \\
\hline \multirow{3}{*}{ 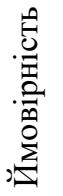 } & Низька & Дрібна & Терпима & Помірна \\
\hline & Середня & Терпима & Помірна & Значна \\
\hline & Висока & Помірна & Значна & Нестерпна \\
\hline
\end{tabular}

Запропонована методика потребує ретельного аналізу 3 метою оцінки ефективності прийняття рішення щодо першочерговості та періодичності проведення планових перевірок суб'єктів господарювання в залежності від комбінації ймовірності виникнення у них непередбачуваних подій та наслідків шкоди від цих подій.

Такий аналіз, проведений наглядовим органом, має на меті визначити найбільш притаманні для кожної 3 ризиконебезпечних галузей економіки України кількість та щільність здійснення заходів державного нагляду та першочерговість проведення інспекційних відвідувань травмонебезпечних підп- риємств, а також надає додаткові стимули, можливості і перспективи, щодо внесення змін у законодавство України в частині зміни підходів до планування інспекційної діяльності за даною методикою (табл. 6). Необхідними умовами реалізації нової методики організації державного нагляду на основі оцінки ризику виробничого травматизму у лісовому господарстві $\epsilon$ наявність постійно поновлюваних статистичних даних, що характеризують умови праці та наслідки їх впливу на працюючих, а також відповідного математичного та програмного забезпечення.

Таблиця 6 - Визначення періодичності планових перевірок на основі ймовірності виникнення та очікуваної тяжкості шкоди

\begin{tabular}{|c|c|c|c|}
\hline \multicolumn{3}{|c|}{$\begin{array}{c}\text { Характеристика тяжкості шкоди та ймовірність виникнення } \\
\text { непередбачуваної події }\end{array}$} & \multirow{2}{*}{$\begin{array}{c}\text { Періодичність планових переві- } \\
\text { рок суб'єктів господарювання } \\
\text { лісової галузі }\end{array}$} \\
\hline Ймовірність & Характеристика тяжкості шкоди & Вага / бали $N D$ & \\
\hline Низька & Дрібна & 1 & $\begin{array}{c}\text { Не частіше одного разу на п’ять } \\
\text { років }\end{array}$ \\
\hline Середня & Терпима (Помірна) & 3 & Не рідше одного разу на три роки \\
\hline Висока & Значна & 6 & Не рідше одного разу на два роки \\
\hline Надвисока & Нестерпна & 10 & Не рідше одного разу на рік \\
\hline
\end{tabular}

ВИСНОВКИ ТА ПРОПОЗИЦІї. Проаналізувавши динаміку змін частки охоплення державним наглядом суб'єктів господарювання лісової галузі та порівнявши iï з річною динамікою змін коефіцієнту тяжкості нещасних випадків у лісовому господарстві, можна зробити висновок, що в Україні спостерігається негативна тенденція щорічного збільшення коефіцієнту тяжкості при зменшенні кількості перевірених суб'єктів господарювання галузі та його зменшення під час активізації перевірок підприємств лісового господарства посадовими особами Держпраці.
У той же час, введення в Україні мораторію на здійснення заходів державного нагляду, негативно вплинуло не тільки на збільшення коефіцієнту тяжкості виробничого травматизму, а i на загальний тренд збільшення рівня виробничого травматизму із смертельними наслідками у лісовому господарстві.

Проведене дослідження підтвердило вплив заходів державного нагляду за додержанням законодавства у сфері охорони праці, в частині того, що збільшення коефіцієнту тяжкості потерпілих від нещасних випадків у лісовому господарстві відбувається 
при зменшенні кількості перевірених у галузі суб'єктів господарювання та їх виробничих об'єктів, а його зменшення реєструється під час активізації перевірок посадових осіб Держпраці.

3 метою підвищення ефективності діяльності наглядового органу у виконанні завдань, визначених Положенням про Держпраці, що полягають у реалізації державної політики у сферах промислової безпеки, охорони та гігієни праці, що в кінцевому випадку сприяє покращенню бізнес-клімату в державі і у подальшому допоможе прискорити узгодження та реалізацію міжнародних угод, міжнародних і європейських трудових норм в Україні, КМУ слід розглянути питання про унеможливлення впровадження таких мораторіїв у подальшому.

Планування наглядової діяльності територіальними органами Держпраці доцільно проводити на основі оцінки виробничих ризиків з урахуванням ймовірності виникнення непередбачуваних подій (аварій, нещасних випадків, інцидентів та ін.) і очікуваної тяжкості від їх шкоди.

Враховуючи зазначене, автором вперше запропоновано при збігу у суб'єктів господарювання факторів надвисокої ймовірності виникнення непередбачуваної події та нестерпної характеристики тяжкості шкоди, віднести їх до суб'єктів господарювання 3 надвисоким ступенем ризику для безпеки життя і здоров'я працюючих та визначити періодичність проведення планових перевірок цих суб'єктів не рідше одного разу на рік.

\section{ЛІТЕРАТУРА}

1. Малихін О. В., Таірова Т. М. Визначення впливу кількісних та якісних показників наглядової діяльності на рівень виробничого травматизму залежно від специфіки галузей виробництва : звіт про науково-дослідну роботу. Київ : ДУ ННДІПБОП, 2014. 153 c.

2. Методика визначення ризиків та їх прийнятих рівнів для декларування безпеки об'єктів підвищеної небезпеки. Київ : Основа, 2003. 192 с.
3. Інформаційно-аналітична довідка Державної служби України з питань праці про підвищення ефективності здійснення державного нагляду за станом охорони праці на підприємствах лісового господарства. Київ : Держпраці, 2019. 37 с.

4. Річні звіти Державної служби України з питань праці за формою 4-3Т.

5. Інформація Державної служби статистики України. URL : http://www.ukrstat.gov.ua (дата звернення 29.11.2018).

6. Радіонов М. О, Козловська Т. Ф. Підвищення ефективності здійснення державного нагляду за станом охорони праці на підприємствах сільського господарства. Вісник Кременчуиького державного університету імені Михайла Остроградського. 2018. Вип. 1/2018 (108). С. 136-146.

7. Річні звіти Державної служби України з питань праці за формою 3-НД.

8. Радіонов М. О. Підвищення ефективності здійснення державного нагляду за станом охорони праці на підприємствах лісового господарства. 3бірник наукових праць «Проблеми охорони праџі в Україні». Київ : ДУ ННДІПБОП, 2017. Вип. 33. C. 101-111.

9. Інформаційні матеріали Міжнародної організації праці з питань управління ризиками на робочому місці та систем управління безпекою і гігієною праці. Київ : ILO, 2018. 104 с.

10. Безпека та гігієна праці у лісовому господарстві. Проект ЄС-МОП Зміцнення адміністрації праці з метою покращення умов праці і подолання незадекларованої праці : навч. посібник. Київ : ILO, 2018. Част. II. 179 с.

11. Гогіташвілі Г. Г., Карчевські В. М., Лапін В. М. Управління охороною праці та ризиком за міжнародними стандартами : навч. посібник. Київ : Знання, 2007. 367 c.

\section{ORGANIZATION OF STATE SUPERVISION IN FORESTRY HOUSEHOLDS WITH THE FACILITATION OF THE POSSIBILITY OF EXCLUSION OF UNSEADED EVENTS AND EXPECTED SEVERITY OF DAMAGE}

\section{Radionov}

Department of oversight of industry and objects of high danger of the State Service of Ukraine for Labor (Department of Supervision in the Agro-Industrial Complex and Socio-Cultural Area)

vul. Desyatinna, 14, Kyiv, 01601, Ukraine. E-mail: radionovnikolay75@gmail.com

Purpose. Issues of organization of state supervision in forestry enterprises are covered. The negative impact of the moratorium on carrying out inspections of forestry business entities on the state of labor protection at the indicated enterprises has been proved. The level of traumatism and its frequency are analyzed. The types of events that have resulted in accidents with mortal consequences have been determined. The definition of the concept of risk and occupational risk is given. Methodology. It has been determined that: risk management includes the collection and analysis of information on occupational safety at each workplace, risk analysis and industrial safety control; risk analysis is a key element in ensuring security based on the information gathered and identifies measures to control the safety of industrial facilities; the risk analysis procedure is an integral part of the declaration of the safety of industrial facilities, the examination of industrial safety, economic analysis of safety and other types of analysis and assessment of the safety state of industrial facilities and areas where possible man-made disasters and emergencies. The principles of the risk-oriented approach to the organization of state supervision in forestry enterprises and the model of risk assessment based on a combination of the probability of occurrence and the expected severity of damage from unpredictable events are considered. Practical value. It is proposed to carry out supervisory planning by the territorial authorities of the State Labor Organization on the basis of assessment of industrial risks taking into account the probability of unforeseen events (ac- 
cidents, incidents, etc.) and the expected gravity of their harm. Proposals on ways to improve the effectiveness of public oversight in forestry enterprises, including on the basis of application of the principles of risk-oriented approach are given. The author proposes, when coinciding with the subjects of management factors of a high probability of occurrence of an unpredictable event and intolerable characteristic of the severity of harm, to attribute them to the subjects of management with a high degree of risk for the safety of life and health of people and to determine the frequency of planned inspections at least once per year. References 11, table 6, figure 3.

Key words: state supervision, forestry, risk, risk assessment, likelihood of occurrence of a certain dangerous event, expected severity of harm.

\section{REFERENCES}

1. Malichin, O. V., Tayrova, T. M. (2014), Vyznachennia vplyvu kilkisnykh ta yakisnykh pokaznykiv nahliadovoi diialnosti na riven vyrobnychoho travmatyzmu zalezhno vid spetsyfiky haluzei vyrobnytstva : zvit pro naukovo-doslidnu robotu [Determination of the influence of quantitative and qualitative indicators of supervisory activity on the level of occupational injuries, depending on the specifics of the industries : Report on the research work], NDIPBOP, Kyiv, Ukraine.

2. Metodyka vyznachennia ryzykiv ta yikh pryiniatykh rivniv dlia deklaruvannia bezpeky obiektiv pidvyshchenoi nebezpeky [Methodology for determining the risks and their levels for declaring the safety of highrisk objects] (2003),, Osnova, Kiev, Ukraine.

3. Informatsiino-analitychna dovidka Derzhavnoi sluzhby Ukrainy $z$ pytan pratsi pro pidvyshchennia efektyvnosti zdiisnennia derzhavnoho nahliadu za stanom okhorony pratsi na pidpryiemstvakh lisovoho hospodarstva [Information and analytical certificate of the State Labor Organization on increasing the efficiency of the state supervision over the state of labor protection at forest enterprises], (2019), State Labor Servis, Kyiv, Ukraine.

4. Annual reports of the State Labor Service 4-JI form.

5. Informatsiia Derzhavnoi sluzhby statystyky Ukrainy [Information of the State Statistics Service of Ukraine] (2018), URL: http://www.ukrstat.gov.ua.

6. Radionov, M. O., Kozlovs'ka, T. F. (2018), "Improving the effectiveness of state supervision over the state of labor protection at agricultural enterprises", Transactions of Kremenchuk Mykhailo Ostrohradskyi National University, vol. 1, no. 108, pp. 136-146.

7. Annual reports of the State Labor Service 3-SA form.

8. Radionov, M. O. (2017), "Improving the effectiveness of state supervision over the state of labor protection at forest enterprises", State enterprise "National Research Institute of Industrial Safety and Occupational Safety". Problems of labor protection in Ukraine : Collection of scientific works. pp. 101-111.

9. Informatsiini materialy Mizhnarodnoi orhanizatsii pratsi $z$ pytan upravlinnia ryzykamy na robochomu mistsi ta system upravlinnia bezpekoiu $i$ hihiienoiu pratsi [Information materials of the International Labor Organization on risk management], (2018), ILO, Kiev, Ukraine.

10. Bezpeka ta hihiiena pratsi u lisovomu hospodarstvi. Proekt YeS-MOP Zmitsnennia administratsii pratsi $z$ metoiu pokrashchennia umov pratsi $i$ podolannia nezadeklarovanoi pratsi [Safety and health in forestry. EU-ILO Project "Strengthening the Labor Administration to Improve Labor and Overcome Undeclared Labor"], (2018), Part II, ILO, Kiev, Ukraine.

11. Gogitashvili, G. G., Karchevsky, V. M., Lapin, V. M. (2007), Upravlinnia okhoronoiu pratsi ta ryzykom za mizhnarodnymy standartamy : navch. posibnyk [Management of Occupational Health and Risk according to International Standards: Teaching Manual], Znannya, Kiev, Ukraine.

Стаття надійшла 28.02.2019. 